DOI 10.22363/2618-897X-2021-18-2-185-193

Research Article

\title{
Buryat Crossroads: Poetry and Mythological Thinking
}

\author{
Z.A. Kuchukova, L.B. Berberova \\ Kabardino-Balkarian State University named after Kh.M. Berbekov \\ 173, Chernyshevsky St., Nalchik, KBR, 360004, Russian Federation \\ Financial University under the Government of the Russian Federation \\ 15, Verkhnyaya Maslovka, Moscow, 127083, Russian Federation
}

\begin{abstract}
The authors give a literary assessment of the monograph by I.V. Bulgutova «Buryat philosophical lyrics: mythopoetic foundations and traditions» with the involvement of some of her other works. A set of questions is studied related to the Buryat mythological school, the mythogenicity index of the Buryat professional literature, various types of mythological thinking, zoonymous mythical plots, the shamanistic cycle, the mythologization of history, and ethno-poetic constants. The practical part of the monograph under review is a mytho-ontological analysis of representative philosophical poetic texts by D. Ulzytuev, L. Tapkhaev, B. Syrenov, G. Radnaeva, R. Shoymardanova. Much attention is paid to the features of the Buryat Russian-language poetry, represented by the works of N. Nimbuev and B. Dugarov.
\end{abstract}

Key words: Buryat poetry, mythopoetics, philosophical lyrics, monograph, I.V. Bulgutova, constants, figurative system, bilingualism, intertext

\section{Article history:}

Received: 02.01.2021

Accepted: 14.03.2021

Moderator: U.M. Bakhtikireeva

\section{Conflict of interests: none}

\section{For citation:}

Kuchukova, Z.A., and L.B. Berberova. 2021. "Buryat Crossroads: Poetry and Mythological Thinking". Polylinguality and Transcultural Practices, 18 (2), 185-193. DOI 10.22363/2618897X-2021-18-2-185-193

(C) Kuchukova Z.A., Berberova L.B., 2021

This work is licensed under a Creative Commons Attribution 4.0 International License https://creativecommons.org/licenses/by/4.0/ 


\title{
Бурятский перекресток: мифомышление и поэзия
}

\author{
З.А. Кучукова, Л.Б. Берберова \\ Кабардино-Балкарский государственный университет им. Х.М. Бербекова \\ Российская Федерация, 360004, КБР, Нальчик, Чернышевского, 173 \\ Финансовый университет при Правительстве РФ \\ Российская Федерация, 127083, Москва, Верхняя Масловка, 15
}

\begin{abstract}
Аннотация. Авторы дают литературоведческую оценку монографии И.В. Булгутовой «Бурятская философская лирика: мифопоэтические основы и традиции» с привлечением и некоторых других ее работ. Исследован комплекс вопросов, связанных с бурятской мифологической школой, индексом мифогенности бурятской профессиональной литературы, разными типами мифомышления, зоонимическими мифосюжетами, шаманским циклом, мифологизацией истории, этнопоэтическими константами. Практическая часть рецензируемой монографии представляет собой мифоонтологический анализ репрезентативных философских поэтических текстов Д. Улзытуева, Л. Тапхаева, Б. Сыренова, Г. Раднаевой, Р. Шоймарданова. Большое внимание уделяется особенностям бурятской русскоязычной поэзии, представленной творчеством Н. Нимбуева и Б. Дугарова.
\end{abstract}

Ключевые слова: бурятская поэзия, мифопоэтика, философская лирика, монография, И.В. Булгутова, константы, образная система, билингвизм, интертекст

\section{История статьи:}

Дата поступления в редакцию: 02.01.2021

Дата принятия к печати: 14.03.2021

Модератор: У.М. Бахтикиреева

Конфликт интересов: отсутствует

\section{Для цитирования:}

Кучукова З.А., Берберова Л.Б. Бурятский перекресток: мифомышление и поэзия // Полилингвиальность и транскультурные практики. 2021. Т. 18. № 2. C. 185-193. DOI $10.22363 / 2618-897$ X-2021-18-2-185-193

\section{Introduction}

The modern globalizing and modernizing society with particular clarity shows the relevance of issues related to the preservation of the all-Russian socio-cultural identity, which consists of a multitude of "daughter identities", which, according to the established tradition, have recently been clearly displayed on the covers of dissertations on Russian literature - the North Caucasus, Kalmykia, the Urals, Volga region, Karelia, Russian North, Siberia, Far East. This kind of geographical "mosaic" is perceived as an order to every Russian humanities scholar to study the ethnocultural characteristics of their own "homelandscape" [1. P. 30]. 
For a good reason modern politicians place the issue of preserving socio-cultural identity on the same logical level with the country's state security in terms of their vital importance. We may add to this the academic behest of the philosopher, culturologist and literary critic G.D. Gachev to preserve for the descendants that very magnificent "orchestra" of humanity, where each nation plays its own, well-defined musical instrument, where "the oboe is dear to the violin because one can do what another cannot" [1. P. 239].

In full accordance with these social challenges and the Gachev way of thinking, Irina Vladimirovna Bulgutova has written the monograph "Buryat Philosophical Lyrics: Mythopoetic Foundations and Traditions", published in Ulan-Ude in 2017. The relevance of the study is due to the need for the modern Buryat literature to identify and scientifically comprehend its own historical roots, to measure the "culture-genic" potential and passionate power of the ancient mythopoetic matrices, capable (or not) still able to "ferment" literary texts.

\section{Discussion}

A few words about the specifics of the monograph. The fact is that, without exception, every nation on earth has a "mythological cradle". At the same time, however, what matters is the distance or the degree of alienation of modern artistic culture of a given nation from the mythopoetic first bricks that laid its foundation. In this respect, the Buryat (Siberian) national culture can rightfully be ranked as "strongly myphogenic". In fact, there is hardly any other nation on the "planet of people" whose social, communicative, cultural, spiritual self-realization is still in practice carried out through mythological ideas, shamanic ritual scenarios that are at arm's length. It's like mammoths being extinct long ago elsewhere, but grazing in someone's garden nowadays. Another specific feature of the investigated I.V. Bulgutova's mythological material is its tight interconnection with Buddhist religious beliefs, which, undoubtedly, make certain adjustments to the overall picture of the mythological ideas of the Buryats.

It is not an easy task to isolate mythologemes and archetypes remaining in such a heterogeneous, "stirring" material and trace their transhistorical and transcultural path with all possible refractions in other artistic worlds. Here, in many respects, the guarantor of scientific research success was the skill of I.V. Bulgutova to think systematically with the involvement of heuristic methods and many other related disciplines - folklore, ethnography, linguistics, psychology, pedagogy, archeology, philosophy, sociology, into her literary criticism. To her credit, she clearly speaks in terms of categories of the named sciences. But even more effective methodological support for her work is the fact that the author is an ethnophor, that is, a scientist who, by the will of fate, is placed at the epicenter of the studied ethnoculture, who knows all its nuances from the inside at the cognitive and scientific levels.

In the theoretical prerequisites for the study, the scientist examines the exploration degree of the parallel "myth - literature" in the world humanities. The methodological basis of the work is the legacy of G.D. Gachev, A.F. Losev, V.Y. Propp, V.N. Toporov, O. Freudenberg, J. Fraser, K. Jung. When researching issues related to mythopoetics, the author turns to the experience of Siberian literary scholars - G.O. Tudenova, T.N. Ochirova, L.S. Dampilova, T.M. Dugarzhapova, E.E. Baldanmaksarova. In order 
to complete the picture, the author examines the essence of mythopoetics from an ethnographic, psychological, historical point of view, simultaneously identifying polyconceptual interpretations and approaches, as well as systematizing terms and concepts necessary for further analysis.

It should be noted that when working with sources, I.V. Bulgutova is not limited to approving quotations of her predecessors, but skillfully and methodically competently develops their thoughts in the direction provided by the search tasks of the monograph.

Figuratively speaking, from each of the studied authors the researcher takes the discursive "threads" connecting myth and literature, which, as a result of careful reflexive work, are formed into a single powerful theoretical "rope", into the scientific concept that mythologism is directly related to the process of linguistic modeling and generation of ethnoculturally determined semiotic system. Solidarizing with M.M. Bakhtin, who noted that culture "is all located on the borders" [2. P. 282], I.V. Bulgutova chose the frontier, the borderline between mythology and literature, as the main place of her "working space", tracing, recording and interpreting the entire conglomeration of direct and indirect "metaphorical metamorphoses" arising from the transition of the mental concept from the sphere of mythology to the sphere of professional literature.

The activities of the Buryat mythological school - this is how briefly we can specify the essence of the introduction to the monograph, where I.V. Bulgutova reproduces in a concise form the history of collection, attribution, systematization and scientific comprehension of numerous legends, traditions, fairy tales, shamanic poetic texts with their intra-genre and dialect modifications.

The author takes into account the conceptual provisions contained in the works of N.O. Sharakshinova "Myths of the Buryats", L.S. Dampilova "Shamanic chants of the Buryats: poetics and symbolism", S.I. Garmaeva "Typology of artistic traditions in the prose of Buryatia", B.D. Bayartueva "Prehistory of Buryat-Mongol Literature", E.A. Ulanova "Folklore in the context of Buryat verbal creativity", T.B. Balarieva "Folklore and modern Buryat prose", L.V. Babkinova "Mythopoetics of modern Buryat poetry", O.A. Zabanova "Space and Time in the Poetry of L.D. Tapkhaev", S.D.-N. Malzurova "Myth-folklore origins of the prose of the peoples of Siberia and Russian North of the 60 s -80 s. of XX century". As it is clear from the monograph, the main achievements of the Buryat mythological school by the end of the 20th century boil down to the following:

1) almost all mythological texts were written "under the dictation of the people" (V.G. Belinsky);

2) a mythological dictionary was created;

3) a scientific classification of Buryat myths (cosmogonic, anthropomorphic, matriarchal, magical, animistic) has been made.

All further research work of I.V. Bulgutova, with all the disciplining headings of subsequent chapters and sections, is devoted to the study and measurement of the mythogenicity index of Buryat fiction. The author is most interested in the link "myth and literature" with the definition of all possible correlations between these two systems (direct connection, allusion, echoing, opposition). In this respect, author's "neurolinguistic" reasoning about two fundamentally different types of myth-thinking is of great scientific interest - that of a "traditionalist artist" and a "bilingual artist". 
I.V. Bulgutova defines the first case as the original unconscious mythologization, since a native speaker initially thinks in mythologems, which are the living operators of the language. A "traditionalist artist" does not need to invent anything - everything is already in the resources of his native language, moreover, he has at his disposal synesthetic images, which are a plexus of wires of hearing, smell, touch, taste, vision [3. P. 124]. A completely different case is the conscious mythologization inherent in Russian-speaking Buryat artists, who are strong in their idiographic searches, aestheticization of mythologemes and archetypes, as well as literary games aimed at highlighting some subtle semantic facets of canonical myths.

As the researcher shows, at the initial stage, mythology is inseparable from the ontology of folk life, the thinking of "children of nature". Mythology replaces all educational subjects from astronomy to biology; it is spread throughout the entire domesticated territory of the steppe dwellers in the form of "speaking" toponyms, oronyms, hydronyms, anthroponyms, calendrical and ritual texts. In full accordance with the theory of G.D. Gachev "Cosmo-Psycho-Logos" [1. P. 34], the researcher emphasizes the special status and the highest frequency of zoonymic myths in the Buryat artistic psyche due to the practical and emotional closeness of the representatives of these cattle herders to the representatives of the animal world. The author illustrates this with the unique texts "The Song of the Horse", "The Song of the Dog", "The Song of the Wolf", "The Song of the Cow", etc. Note that the animalistic theme "has a wide cultural significance, since the issues of ethics and aesthetics intersect here" [4. P. 20].

In the chapter "Myth and Epic Plot in Buryat Literature" I.V. Bulgutova explores the degree of plasticity and "malleability" of the mythological tools for recording events that are significant in the national history of Buryatia. It should be said that the entire chapter is actually a field of intersection of history with ontology. With reference to A.F. Losev, the author at the very beginning writes that "mythical consciousness should give words about historical facts, a story about the life of individuals [3. P. 15]. "Words" here, undoubtedly, should be understood in an expansive sense, since in fact we are talking not only about vocabulary or artistic images, but also such phenomena as "plot building", "composition", "duplication", "retardation", "cyclical and cumulative narrative schemes", "chronotope", "architectonics".

All these forms of "patronage" of the myth over epic literature in the monograph by I.V. Bulgutova are comprehensively considered on the example of the historical novels of Ts. Galanov "Mother Swan", V. Garmaev "The Tenth Rabjun", dramatic poems by N.G. Damdinov "Shelday zangi tukhai duun", N.G. Baldano "Enkhe-Bulat Bator". From the literary point of view, the study of the plot-forming function of mythconsciousness on the basis of the stories and short novels of B. Yabzhanov with his narration-in-first-person manner is of great interest. As a result of their subtle artistic analysis (in particular, the story "The Stone Thrown Up"), such specific phenomena as the conflict between herbivores and predators, Buddhist ideas of the karmic predetermination of a person's fate by his actions, totemic views of the characters, the author's leaning towards parable allegory are revealed and described.

Undoubtedly, the most unique place in the entire "Siberian hypertext" is occupied by shamanic themes, which also found their full reflection in the scientific work of 
I.V. Bulgutova. Most importantly, the researcher showed that shamanistic beliefs are not an annoying anachronism (as was once noted by Soviet ideologists), but an ancient ideological complex that keeps producing new cultural meanings. The author has assembled a whole "shamanic cycle", consisting of literary texts of different genres (drama by B. Baradin "The Great Shaman-Sister", novels by A. Balburov "Singing Arrows", A. Gatapov "Temujin", V. Garmaev "Diggers", V. Baraev "Uliger on childhood”, etc.), each of which is an original form of embodiment of mythopoetic views associated with oneiric motives, motives of werewolf, subject letters, national traditions of calculating space and time, symbolism of the objective world. Th author has analyzed in detail the mythologemes "ancestral river", "paths of ancestors", "smallpox", "birch bark basket with arza", interpreted the meaning of different names of the moon, and even noted such subtleties as "special fertility of soil from under the circles left on the place of shaman's yurts" [5. P. 16-19].

The chapter "Mythological motives in the Buryat philosophical lyrics" is a synchronous cut of the contemporary poetic art of Buryatia for the purpose of identifying the key ethnoculturally conditioned mythologemes. The author actually tailored a single artistic canvas from the poetic texts of L. Tapkhaev, D. Ulzytuev, Zh. Yubukhaev, B. Sirenov, G. Radnaeva, R. Shoymardanov, D.-R. Dambaev, N. Nimbuev. I.V. Bulgutova passes all this heterogeneous material, complicated by religious, stylistic, generational, ideological, urban, globalistic factors, through the "sieve" of mythoontological poetics to determine the stability of archaic prototypes and their ability to adapt to the realities of the 21st century. For completeness of the diagnosis, such components of mythopoetics as chronotope (night or day), architectonics, color symbolism, metaphor, epithet, repetition, sensory, kinetic and textured images, nominology, numerology, alliteration, antithesis, selectivity of poetic sizes are investigated.

As the researcher shows, after such a multilayer control, a set of mythological codings is exposed, such as "consubstantiality of biorhythms of nature and man", "isomorphism of man and planetary structure", "comparability of cosmic phenomena with household items", "dominant of zoomorphic images", "environmental friendliness of consciousness", "the idea of an eternal circle", "the cult of the Teacher", "a circle of karmic predeterminations", "the motive of the soul rebirth", "the indivisibility of the subject and the object", "the dynamic path of the nomad", which together constitute the essence of the spiritual quest of modern Buryats.

Among the innovative features the author calls: linking religious mythological images with the scientific picture of the world; the tendency to abandon voluminous literary genres in favor of the short ones; the theme of the conflict between the steppe and technogenic civilization; creative development of foreign cultural poetic genres (free verse, tanka, hokku); literary game with mythopoetic constants. A striking example of this is the Buryat proverb "A saddled horse will fit in the heart of a man", played out in an ironic way by N. Nimbuev [3. P. 127].

As the original and scientifically grounded conclusion of the researcher states, Buryat mythology successfully passes the "test of influences", and any foreign cultural "influence passes through the filters of the local tradition" [3. P. 123]. In other words, even at the present stage, mythological views and traditional values continue to "prevent chaos" and play the role of a navigator of artistic consciousness in the Buryat ethnocultural space. 
Among the remarkable features and advantages of the monograph under review, we would like to note a few more points. One is - constantly drawn intertextual parallels of "Siberian texts" with typologically similar phenomena in world culture (Homer, O. Khayyam, Marquez, F. Cooper, W. Whitman, Rilke, Apollinaire, Exupery, Basho, L.N. Tolstoy, A.S. Pushkin, M.Yu. Lermontov, I. Severyanin, V. Mayakovsky, B. Pasternak, Ch. Aitmatov, V. Rasputin and others), which emphasize the commonality of human thinking. Almost always, the author in her works translates Buryat exoticisms and ethnographisms into Russian, and also explains their etymology, which is very important, since in most cases they are mythologemes. Throughout the study, I.V. Bulgutova does not let the female discourse of texts out of sight, which greatly facilitates the work of future Siberian gender researchers. This is especially true for the sections devoted to the analysis of stories about the heroic Balzhan-Khatan, as well as female images in the work of the Buryat poetess Galina Radnaeva. Throughout the work, as the main line runs the theme of environmental education and environmental culture, expressed by nameless storytellers, professional writers of Buryatia and the researcher herself. This is of great educational value.

Separately, it should be said about the phenomenon of bilingualism, which is interpreted by most modern theorists as a threat to national linguistic identity. We find a very original judgment on this score in a recently published article by linguists U.M. Bakhtikireeva and B. E. Shagimgereeva, dedicated to the "linguistic biography" of Bakhyt Kairbekov: " Cross-pollination" of cultures in one society determines the formation of a special type of personality - a bilingual, multicultural, creative, or so-called marginal person who perceives the culture of his people from the inside and outside, which means more stereoscopic vision and more dimensional thinking than monolingual» [6. P. 87]. We agree that this explicit statement marks a conceptual and constructive turn in solving the problems of the writer's ethnic identification and bilingualism. The idea of "crosspollination" is also supported by a Buryat researcher, who, while legalizing a bipolar view of the works of bilingual writers in general, notes that "works written on the borderlands of the Buryat and Russian cultures are perceived integrally and consistently in the context of both" [3. P. 162].

Speaking at one of the scientific seminars, V.P. Sinyachkin rightly noted that "polylingualism arises when within one phenomenon of reality, various code systems are intertwined, resulting in more complex, sometimes hybrid objects" [7. P. 666]. Based on the creative work of a whole galaxy of Russophonic authors in Buryatia, I.V. Bulgutova showed the specifics of polycode imagery systems, where, paradoxically, "one" plus "one" equals not "two", but "three", that is, there is not an arithmetic sum, but a certain original semantic complex.

\section{Recommendations and conclusion}

In our opinion I.V. Bulgutova successfully completed her task of comprehension of the functional role of mythologemes in the national literature. The novelty of the results obtained is significant. For the first time, all forms of mythological intertextmes in Buryat poetry are considered on such a large scale, depicting the evolutionary transition from "direct communication" to "literary play" with many intermediate stages. Towards the 
end, we would like to note several promising topics that are asking to enter the "myth and literature" discourse arena.

1. In the section where the author discusses the specifics of linguistic modeling in the context of mythopoetics, the Sapir-Whorf theory is regrettably ignored, whereas it could lead the author to interesting arguments about cognitive processes and the fundamental controllability of human consciousness (a conventional Siberian) by mythological metacodes.

2. Since "a child is a primitive little-man", in children's poetry, as in the alphabet, the features of mythological logic are reflected as large and vividly as possible. That is why, in our opinion, it would be advisable in the future to pay special research attention to the samples of children's Buryat poetry.

3. In the work of I.V. Bulgutova we can clearly trace the transhistorical, dynamic movement of primordial mythologemes within Buryat literature with all possible transformations, refractions, inversions. As the ultimate evolutionary point in the work, N. Nimbuev's ironic literary game with the mythologeme about "a horse in a man's heart" is recorded [3. P. 127]. So what is next? It remains unclear whether there are cases of complete postmodern deconstruction of mythological plots in contemporary Buryat poetry. In this regard, for further researches we recommended to consider the postNimbuean art of the next-generation.

Developed by I.V. Bulgutova mytho-ontological method of analyzing a literary text can be successfully used in the study of other national literatures of the Russian Federation by folklorists, literary critics, ethnologists, orientalists, as well as graduate students, bachelor and master students of humanitarian universities.

\section{References}

1. Gachev, G.D. 2003. Mental'nosti narodov mira. Moscow: Izd-vo Eksmo. Print. (In Russ.)

2. Bakhtin, M.M. 2003. "K voprosam metodologii estetiki slovesnogo tvorchestva". In Collected Works. Vol. 1. Moscow: Russkie slovari: Yazyki slavyanskoj kul'tury. P. 282. Print. (In Russ.)

3. Bulgutova, I.V. 2017. Buryatskaya filosofskaya lirika. Mifopoeticheskie osnovy i tradicii. Ulan-Ude: Izdatel'stvo Buryatskogo gosuniversiteta. Print. (In Russ.)

4. Berberov, B.A. 2004. "Hudozhestvennye osobennosti vyselencheskogo fol'klora karachaevcev i balkarcev”. Kul'turnaya zhizn’ Yuga Rossii 3 (9): 18-21. Print. (In Russ.)

5. Bulgutova, I.V. 2019. "Mifopoetika v kontekste stanovleniya i razvitiya buryatskoj literatury vtoroj poloviny XX - nachala XXI vekov". Candidate Thesis. Ulan-Ude, 2019. Print. (In Russ.)

6. Bahtikireeva U.M., Shagimgereeva B.E. 2020. "Yazykovoe bytie tvorcheskoj lichnosti: Bahyt Kairbekov". Social'nye i gumanitarnye nauki na Dal'nem Vostoke 17 (1): 83-89. Print. (In Russ.)

7. Sinyachkin, V.P. 2019. "Interuniversity Seminar "Russia and China: Literary Receptive Aesthetics", October 3, 2019, Moscow". Polylinguality and Transcultural Practices 16 (4): 666-669. doi: 10.22363/2618-897X-2019-16-4-666-669

\section{Список литературы}

1. Гачев Г.Д. Ментальности народов мира. М.: Эксмо, 2003.

2. Бахтин М.M. К вопросам методологии эстетики словесного творчества // Собрание сочинений. Т. 1. М.: Русские словари: Языки славянской культуры, 2003.

3. Булгутова И.В. Бурятская философская лирика. Мифопоэтические основы и традиции: монография. Улан-Удэ: Издательство Бурятского госуниверситета, 2017. 
4. Берберов Б.А. Художественные особенности выселенческого фольклора карачаевцев и балкарцев //Культурная жизнь Юга России. 2004. №3 (9). С. 18-21.

5. Булгутова И.В. Мифопоэтика в контексте становления и развития бурятской литературы второй половины XX - начала XXI веков: автореф. дис. ... д-ра филол. наук. Улан-Удэ, 2019.

6. Бахтикиреева У.М., Шагимгереева Б.Е. Языковое бытие творческой личности: Бахыт Каирбеков // Социальные и гуманитарные науки на Дальнем Востоке. 2020. T. XVII. Вып. 1. C. $83-89$.

7. Синячкин В.П. І Межвузовский семинар «Россия и Китай: литературная рецептивная эстетика». 3 октября 2019 года, Москва //Полилингвиальность и транскультурные практики. 2019. T. 16. № 4. C. 666-669. DOI 10.22363/2618-897X-2019-16-4-666-669

\section{Bio Notes:}

Zukhra A. Kuchukova is a Doctor of Philology, Professor of the Department of Russian and Foreign Literature of Kabardino-Balkarian State University named after H.M. Berbekov. E-mail: kuchuk60@list.ru

Liana B. Berberova is a Candidate of Pedagogical Sciences, Senior Lecturer of the Department of Language Training of the Federal State Educational Institution of Higher Education "Financial University under the Government of the Russian Federation”. E-mail: berberova.liana@ yandex.ru

\section{Сведения об авторах:}

Кучукова Зухра Ахметовна - доктор филологических наук, профессор кафедры русской и зарубежной литератур Кабардино-Балкарского государственного университета им. Х.М. Бербекова. E-mail: kuchuk60@list.ru

Берберова Лиана Бурхановна - кандидат педагогических наук, ст. преподаватель Департамента языковой подготовки Финансового университета при Правительстве РФ. E-mail: berberova.liana@yandex.ru 